ISSN 0258-7122

Bangladesh J. Agril. Res. 39(3): 529-545, September 2014

\title{
INFLUENCE OF INTEGRATED ORGANIC-INORGANIC NITROGEN ON GROWTH AND NUTRIENT CONCENTRATION OF SUMMER ONION (Allium cepa)
}

\author{
SAIMA SULTANA ${ }^{1}$, ALOK KUMAR PAUL ${ }^{1}$ \\ DEEDER SULTANA ${ }^{2}$ AND JHARNA RANI SARKER ${ }^{1}$
}

\begin{abstract}
An experiment was carried out to assess the effect of integrated organic and inorganic nitrogen on growth and nutrient concentration in summer onion (Allium cepa var. BARI Piaz-2). The study was done on a silty clay loam soil of Sher-e-Bangla Agricultural University Farm, Dhaka during kharif (March to October) season. The soil of the experimental site belongs to the Tejgaon series of AEZ No. 28, Madhupur Tract, classified as Shallow Red Brown Terrace Soils in Bangladesh soil classification system. Twelve treatments were used in the experiment and in each treatment, different combinations of urea, cowdung, and vermicompost were used to supply nitrogen $(\mathrm{N})$ at the rate of $120 \mathrm{~kg} / \mathrm{ha}$. The treatments were arranged in a RCBD with three replications included-control or no fertilizer supplied $\left(\mathrm{T}_{1}\right), 120 \mathrm{~kg} \mathrm{~N} / \mathrm{ha}$ supplied from urea $\left(\mathrm{T}_{2}\right), 100 \mathrm{~kg} \mathrm{~N} / \mathrm{ha}$ supplied from urea with $20 \mathrm{~kg}$ from cowdung $\left(\mathrm{T}_{3}\right), 100 \mathrm{~kg} \mathrm{~N} / \mathrm{ha}$ supplied from urea with $20 \mathrm{~kg}$ from vermicompost $\left(\mathrm{T}_{4}\right), 80 \mathrm{~kg} \mathrm{~N} /$ ha supplied from urea with 40 $\mathrm{kg}$ from cowdung $\left(\mathrm{T}_{5}\right), 80 \mathrm{~kg} \mathrm{~N} / \mathrm{ha}$ supplied from urea with $40 \mathrm{~kg}$ from vermicompost $\left(\mathrm{T}_{6}\right), 60 \mathrm{~kg} \mathrm{~N} / \mathrm{ha}$ supplied from urea with $60 \mathrm{~kg}$ from cowdung $\left(\mathrm{T}_{7}\right), 60 \mathrm{~kg} \mathrm{~N} / \mathrm{ha}$ supplied from urea with $60 \mathrm{~kg}$ from vermicompost $\left(\mathrm{T}_{8}\right), 40 \mathrm{~kg}$ $\mathrm{N} /$ ha supplied from urea with $80 \mathrm{~kg}$ from cowdung $\left(\mathrm{T}_{9}\right), 40 \mathrm{~kg} \mathrm{~N} / \mathrm{ha}$ supplied from urea with $80 \mathrm{~kg}$ from vermicompost $\left(\mathrm{T}_{10}\right), 120 \mathrm{~kg} \mathrm{~N} / \mathrm{ha}$ supplied from cowdung $\left(\mathrm{T}_{11}\right), 120 \mathrm{~kg} \mathrm{~N} / \mathrm{ha}$ supplied from vermicompost $\left(\mathrm{T}_{12}\right)$. Data on plant height, number of leaves, leaf length, bulb length, and bulb weight of onion were recorded. Samples of bulb and leaf were analyzed for determining the total nitrogen, phosphorous, potassium, and sulphur content. Height of plant ranged from 24.25 to $39.25 \mathrm{~cm}$ with lowest and highest value from $\mathrm{T}_{1}$ and $\mathrm{T}_{5}$, respectively. Like plant height, the longest leaf length $(34.35 \mathrm{~cm})$ and bulb length $(2.79 \mathrm{~cm})$ was observed in $\mathrm{T}_{5}$, whereas the shortest leaf length $(21.20 \mathrm{~cm})$ and bulb length $(2.40 \mathrm{~cm})$ was recorded in $\mathrm{T}_{1}$ treatment. Similarly treatment $\mathrm{T}_{5}$ showed the highest value for both bulb weight $(30.40 \mathrm{~g})$ and bulb yield (12.16 $\mathrm{t} / \mathrm{ha})$, whereas the lowest bulb weight (14.90 g) and bulb yield (5.96 t/ha) was obtained from $T_{1}$ treatment. Statistically insignificant variations were recorded on number of leaves/plant. The highest nitrogen, phosphorous, potassium and sulphur content in bulb $(2.30,0.185,1.71$ and $0.96 \%$, respectively) and in leaf $\left(2.91,0.183,2.45\right.$, and $0.98 \%$, respectively) were recorded in treatment $\mathrm{T}_{5}$. Whereas, the lowest nitrogen, phosphorous, potassium, and sulphur content in bulb $(1.41,0.055,0.89$, and $0.66 \%$, respectively) and in leaf $(2.15,0.053,1.71$
\end{abstract}

${ }^{1}$ Department of Soil Science, Sher-e-Bangla Agricultural University, Dhaka, ${ }^{2}$ Planning \& Evaluation Division, Bangladesh Agricultural Research Institute, Gazipur, Bangladesh. 
and $0.63 \%$, respectively) was found in $\mathrm{T}_{1}$. Therefore, the overall results suggest that treatment $T_{5}$ which supplied $40 \mathrm{~kg} \mathrm{~N} / \mathrm{ha}$ from cowdung and rest $80 \mathrm{~kg}$ from inorganic urea resulted in maximum plant growth and nutrient concentration and can be recommended for optimum production of summer onion.

Keywords: Allium cepa, organic nitrogen, summer onion, growth parameters and vermicompost.

\section{Introduction}

Onion (Allium cepa L.), a member of Amaryllidaceae family is one of the most important mono-cotyledonous spice crop. This most widely used condiment, believed to be originated in Central Asia, possesses tremendous popularity as well as economic importance all over the world. It is currently grown in at least 175 countries worldwide with a total production of 85375 thousand metric tons (FAO, 2011). Among the countries, China, India, United States, Turkey, Pakistan, Russia, South Korea, Japan, Egypt, and Spain are the largest producers. In Bangladesh, it is commercially cultivated in the greater districts of Faridpur, Rajshahi, Manikgonj, Comilla, Mymensingh, Jessore, Rangpur, and Pabna (BBS, 2004). Onion is used as a delicious vegetables and it is very common in almost all food preparations (Hossain and Islam, 1994). People consume onion daily as salad and pickle, as boiled, fried and baked condition as well as in curries (Pandita, 1994).

In 2002-03, the country produced only 153 thousand MT of onion as against the total requirement of 450 thousand MT per year on an area of 38 thousand hectares of land (BBS, 2004). Total area coverage and production of onion in Bangladesh has been increased gradually over the time and in 2010-11, it covers 128 thousand ha of land with a total production of 1051 thousand MT. Although the average yield of onion in Bangladesh reaches around 8.21 MT/ha, but still it is far below than the world average of $19.89 \mathrm{MT} / \mathrm{ha}$ (FAO, 2011). As a thermo and photosensitive crop, optimum temperature for onion cultivation ranges between 13 and $24^{\circ} \mathrm{C}$ (Mallik, 2011). Though once onion is grown only in winter season but with the development of summer tolerant varieties and proper culture techniques, it has now been cultivated in summer season also. Recently BARI has released three summer onion varieties viz., BARI Piaz-2, 3, and 5 for growing in kharif season as its genetic potentiality already proved to be suitable for summer season. Introducing heat and summer tolerant onion variety might help solving shortage of onion production in the country.

Production level can be increased either by increasing the extent of cultivated area or by increasing yield per unit area. However, the possibility to increase the extent under cultivation is less because of limited land resource and also existing land become unsuitable to cultivation due to adverse climatic changes and natural disaster. Cultivation of this nutrient responsive crop using eco-friendly 
innovative techniques like integrated use of organic manures along with inorganic fertilizer for sustainable use of available resources could be best way to increase production level. The importance of macro nutrients, such as nitrogen, phosphorous, potassium, sulphur, zinc, and boron for the growth and yield of vegetable crops is well established. Among all the major nutrients, nitrogen plays an essential role in synthesizing amino acid to increase vegetative growth of onion which ultimately helps in increasing bulb size and total yield (Rai, 1981). Brewster and Butler (1989) and Randle (2000) also stated about influence of nitrogen on development, flavour and quality of onion bulb. Nitrogen also increases the vegetative growth, produces good quality foliage and promotes carbohydrate synthesis (Rai, 1981).

Onion shows significant response to organic and inorganic fertilizers (Nasreen and Hossain, 2000). Therefore, the usage of organic manures as alternative source of nitrogen would give better result in its growth and yield. Organic material, such as farmyard manure improves soil physico-chemical properties that are important for plant growth (Snyman et al., 1998). Decomposition of materials would provide additional nutrients to the growing medium which may lead to higher uptake of nutrient by the crop and subsequently high yield. Besides, organic manures have positive effect on root growth by improving the root rhizosphere conditions (structure, humidity, etc.) and also plant growth is encouraged by increasing the population of microorganisms (Shaheen et al., 2007). Previously in several studies, the effects of integrated use of organic-inorganic nitrogen on yield and quality of onion were investigated. Kumar et al. (2001) found that the application of $120 \mathrm{~kg} \mathrm{~N} / \mathrm{ha}$ increased onion yield to 30\%. Rumpel (1998) researched the effect of 20, 40, 60 t/ha animal manure doses, NPK (75: 50: $100 \mathrm{~kg} / \mathrm{ha}$ ) inorganic fertilizer and combination of these. Researchers have found that addition of animal manure resulted in higher onion yield compared to sole application of inorganic NPK fertilizer. Sharma et al. (2003) reported that 0, 50, and $150 \%$ of the recommended amounts of NPK fertilizers $(125: 33: 50 \mathrm{~kg} / \mathrm{ha})$ with $0,10,20 \mathrm{t} / \mathrm{ha}$ cowdung combination increased onion yield and nutrient uptake. Mixture of chicken manure and bio-fertilizer increases the yield of onion and enriched nutrient content in tuber was reported by Shaheen et al. (2007). Vasanthi and Kumaraswamy (1999) showed that the grain yields of rice were significantly higher in the treatments that received vermicompost from any of the 5 to $10 \mathrm{t} / \mathrm{ha}$ organic materials (sugarcane trash, Ipomoea, banana peduncle, etc.) with $\mathrm{N}, \mathrm{P}$, and $\mathrm{K}$ at recommended levels than in the treatment that received $\mathrm{N}, \mathrm{P}$, and $\mathrm{K}$ alone. Dry matter accumulation, grain yield, and grain protein content in chickpea was considerably improved by the application of $3 \mathrm{t} /$ ha vermicompost (Rao et al., 2000). Keeping this view, the present study was conducted to study the influence of integrated organic and inorganic nitrogen for improving growth and nutrient concentration of summer onion. 


\section{Materials and Method}

Experimental site and crop: The experiment was conducted at Sher-e-Bangla Agricultural University farm in kharif season. The soil of the experimental field belongs to the Tejgaon series of AEZ No. 28, Madhupur Tract, classified as Shallow Red Brown Terrace Soils. The climate is characterized by sub-tropical accompanied by heavy rainfall (average $258 \mathrm{~mm}$ ), high humidity (average $77 \%$ ), high temperature (average maximum and minimum was around 32.2 and $24.6^{\circ} \mathrm{C}$, respectively), relatively long day during the kharif season (BMD, 2007). BARI Piaz-2, a high yielding variety of summer onion was selected for this experiment.

Initial soil parameters: Soil of the experimental site consisted of 24.5, 43.1 and $32.4 \%$ sand, silt and clay, respectively and therefore, regarded as silty clay loam. Initial soil $\mathrm{pH}$ was 6.0 and organic matter content was found $0.83 \%$. Total nitrogen $(\mathrm{N})$, available phosphorous $(\mathrm{P})$, exchangeable potassium $(\mathrm{K})$ and available sulphur $(\mathrm{S})$ of the experimental site's soil were $0.076 \%, 19.72 \mathrm{ppm}$, $0.17 \mathrm{meq} / 100 \mathrm{~g}$ soil and $20.51 \mathrm{ppm}$, respectively.

Experimental design and plot preparation: Light textured and well drained soil was selected for raising seedlings. The size of the seedbeds was $3 \mathrm{~m} \times 1 \mathrm{~m}$ with a height of about $20 \mathrm{~cm}$ above soil level. Onion seeds were soaked overnight in water and allowed to burgeon in a piece of moist cloth keeping in the sunshade for one day. Then seeds were sown directly in the seedbed for raising seedlings. The experiment consisted of 12 treatment combinations and was laid out in Randomized Complete Block Design (RCBD) with 3 replications. An area of 380 $\mathrm{m}^{2}$ was divided into three equal blocks representing the replications, each containing 12 plots. A total of 36 micro plots, each measuring $2 \times 2 \mathrm{~m}^{2}$ were prepared. The distance between plots and blocks was 1 and $1.5 \mathrm{~m}$, respectively. The experimental plot was ploughed and laddered mechanically several times to obtain a desirable tilth of friable soil for transplanting of seedlings. Necessary weeding was done at the same time. Finally, the land was leveled and the experimental plot was partitioned into the unit plots.

Treatments of the experiment: The present experiment consists of 12 treatments where $120 \mathrm{~kg} \mathrm{~N} / \mathrm{ha}$ supplied from different combination of urea, cowdung, and vermicompost. According to the recommendation of Bangladesh Agricultural Research Institute, Urea, TSP, MoP, and gypsum were used at the rate of $260,220,200$, and $180 \mathrm{~kg} / \mathrm{ha}$, respectively. Assuming the $\mathrm{N}$ content of urea, cowdung, and vermicompost is $46,0.5$ and $0.64 \%$, respectively, the amount of manures and fertilizers in each treatment was set exactly to supply $120 \mathrm{~kg} \mathrm{~N} / \mathrm{ha}$. Treatment wise nitrogen supply plan and fertilizer doses are presented in Table 1. 
Table 1. Treatment combination with manure and fertilizer doses.

\begin{tabular}{|c|c|c|c|c|c|c|}
\hline \multirow{3}{*}{ Treatments } & \multicolumn{3}{|c|}{ Source wise amount of $\mathrm{N}$} & \multicolumn{3}{|c|}{ Fertilizer dose } \\
\hline & \multirow{2}{*}{$\begin{array}{l}\text { N from } \\
\text { Urea } \\
\text { (kg/ha) }\end{array}$} & \multicolumn{2}{|c|}{$\mathrm{N}$ from manure substitution } & \multirow{2}{*}{$\begin{array}{l}\text { Urea } \\
(\mathrm{kg} / \mathrm{ha})\end{array}$} & \multicolumn{2}{|c|}{ Manure Substitution } \\
\hline & & $\begin{array}{c}\text { Cowdung } \\
(\mathrm{kg} / \mathrm{ha})\end{array}$ & $\begin{array}{l}\text { Vermicompost } \\
(\mathrm{kg} / \mathrm{ha})\end{array}$ & & $\begin{array}{c}\text { Cowdung } \\
\text { (t/ha) }\end{array}$ & $\begin{array}{l}\text { Vermicompost } \\
\text { (t/ha) }\end{array}$ \\
\hline $\mathrm{T}_{1}$ & - & - & - & - & - & - \\
\hline $\mathrm{T}_{2}$ & 120 & - & - & 260 & - & - \\
\hline $\mathrm{T}_{3}$ & 100 & 20 & - & 215 & 4 & - \\
\hline $\mathrm{T}_{4}$ & 100 & - & 20 & 215 & & 3 \\
\hline $\mathrm{T}_{5}$ & 80 & 40 & - & 174 & 8 & - \\
\hline $\mathrm{T}_{6}$ & 80 & - & 40 & 174 & - & 6.25 \\
\hline $\mathrm{T}_{7}$ & 60 & 60 & - & 130 & 12 & - \\
\hline $\mathrm{T}_{8}$ & 60 & - & 60 & 130 & - & 9.5 \\
\hline $\mathrm{T}_{9}$ & 40 & 80 & - & 87 & 16 & \\
\hline $\mathrm{T}_{10}$ & 40 & - & 80 & 87 & - & 12.5 \\
\hline $\mathrm{T}_{11}$ & - & 120 & - & - & 24 & - \\
\hline $\mathrm{T}_{12}$ & - & - & 120 & - & - & 18.75 \\
\hline
\end{tabular}

Application of manures and fertilizers: The entire amount of TSP, MoP, Gypsum and well decomposed cowdung were added to the soil at the time of final land preparation. Urea was applied in four equal splits and vermicompost was applied in three splits where 50\% in first split and remaining 50\% in two equal splits. Healthy and disease free uniform sized 45 days old seedlings of BARI Piaz-2 were transplanted in the main field with the spacing of $25 \mathrm{~cm} \times$ $10 \mathrm{~cm}$. Intercultural operations were done whenever required for getting better growth and development of the plants. The crop was harvested according to their attainment of maturity showing the sign of drying out of most of the leaves and collapsing at the neck of the bulbs. Five plants were randomly selected from each plot and necessary information was recorded.

Chemical analysis of plant sample: Plants samples were collected, processed and were analyzed for determination of nitrogen $(\mathrm{N})$, phosphorous $(\mathrm{P})$, potassium $(\mathrm{K})$, and sulphur (S) content. Nitrogen was determined by Micro-Kjeldahl method as described by Bremner and Mulvaney (1982). Phosphorus was determined by ascorbic acid blue colour method (Murphy and Riley, 1962) with the help of a Spectrophotometer (LKB Novaspec, 4049), potassium was determined by flame photometer, sulphur was analyzed by turbidimetric method as described by Hunt (1980) using a Spectrophotometer (LKB Novaspec, 4049). 
Statistical analysis: Data obtained from the experiment were analyzed statistically using MSTAT computer package program to find out the significance of the difference among the treatments. The mean values of all the treatment were calculated and analysis of variances for all the characters was performed by the ' $F$ ' (variance ratio) test. The significance of the differences among the pairs of treatment means was estimated by the Duncan Multiple Range Test (DMRT) at $1 \%$ and 5\% level of probability (Gomez and Gomez, 1984) for the interpretation of results.

\section{Results and Discussion}

\section{Growth parameters}

Plant height: A significant variation was observed in plant height of summer onion due to application of $\mathrm{N}$ from organic and inorganic sources (Table 2). Application of $\mathrm{N}$ influenced plant height positively. Among the treatments, urea with cowdung treated plots gave higher plant height compared to urea with vermicompost treated plots. The highest plant height $(39.25 \mathrm{~cm})$ was recorded in $\mathrm{T}_{5}$ ( $80 \mathrm{~kg} \mathrm{~N} / \mathrm{ha}$ supplied from urea with $40 \mathrm{~kg} \mathrm{~N} / \mathrm{ha}$ substituted by cowdung) followed by $T_{6}(80 \mathrm{~kg} \mathrm{~N} / \mathrm{ha}$ supplied from urea with $40 \mathrm{~kg} \mathrm{~N} / \mathrm{ha}$ substituted by vermicompost) with the value of $37.82 \mathrm{~cm}$. In contrast, the lowest plant height $(24.25 \mathrm{~cm})$ was observed in the $\mathrm{T}_{1}$ (control) plot receiving no organic or inorganic fertilizer. Treatment receiving full dose of $\mathrm{N}$ from urea $\left(\mathrm{T}_{2}\right)$, cowdung $\left(\mathrm{T}_{11}\right)$ and vermicompost $\left(\mathrm{T}_{12}\right)$ alone had significantly lower plant height compared to those receiving $\mathrm{N}$ from urea with cowdung and urea with vermicompost. Relatively similar result was found by Reddy and Reddy (2005). They observed that plant height of onion increased significantly with increasing levels of vermicompost (from 10 to $30 \mathrm{t} / \mathrm{ha}$ ) and $\mathrm{N}$ fertilizer (from 50 to $200 \mathrm{~kg} / \mathrm{ha}$ ). Haque et al. (2004) stated that plant height of onion increased with increasing rates of $\mathrm{N}$ up to $125 \mathrm{~kg} / \mathrm{ha}$ and decreased thereafter. Plant height of onion showed increasing trends up to the highest $\mathrm{N}$ rate (Singh et al., 2004). Jayathilake et al. (2003) found that the plant height of summer onion was significantly increased with the application of bio-fertilizers in combination with $50 \% \mathrm{~N}$ applied through organic manure (vermicompost or farmyard manure) while the other $50 \%$ of recommended $\mathrm{N}$ and $100 \%$ phosphorous and potassium were supplied through chemical fertilizer which was significantly superior to the application of chemical fertilizer alone or application of organic manure alone. 
Table 2. Effect of integrated use of nitrogen on the growth parameters and yield of summer onion.

\begin{tabular}{c|c|c|c|c|c|c}
\hline Treatments & $\begin{array}{c}\text { Plant } \\
\text { height } \\
(\mathrm{cm})\end{array}$ & $\begin{array}{c}\text { Number of } \\
\text { Leaves/ plant }\end{array}$ & $\begin{array}{c}\text { Leaf } \\
\text { length } \\
(\mathrm{cm})\end{array}$ & $\begin{array}{c}\text { Bulb } \\
\text { length } \\
(\mathrm{cm})\end{array}$ & $\begin{array}{c}\text { Bulb weight } \\
(\mathrm{g})\end{array}$ & $\begin{array}{c}\text { Bulb } \\
\text { yield } \\
(\mathrm{t} / \mathrm{ha})\end{array}$ \\
\hline $\mathrm{T}_{1}$ & $24.25^{\mathrm{h}}$ & 4.98 & $21.20^{\mathrm{h}}$ & $2.40^{\mathrm{g}}$ & $14.90^{\mathrm{i}}$ & $5.96^{\mathrm{h}}$ \\
$\mathrm{T}_{2}$ & $32.57^{\mathrm{de}}$ & 6.00 & $26.94^{\mathrm{c}-\mathrm{g}}$ & $2.54^{\mathrm{def}}$ & $24.10^{\text {def }}$ & $9.64^{\mathrm{cde}}$ \\
$\mathrm{T}_{3}$ & $37.18 \mathrm{a}^{\mathrm{bc}}$ & 5.67 & $30.97^{\mathrm{abc}}$ & $2.69^{\mathrm{abc}}$ & $28.25^{\mathrm{abc}}$ & $11.30^{\mathrm{ab}}$ \\
$\mathrm{T}_{4}$ & $35.56^{\mathrm{bcd}}$ & 5.00 & $30.16^{\mathrm{a}-\mathrm{d}}$ & $2.65^{\mathrm{bcd}}$ & $27.10^{\mathrm{a}-\mathrm{d}}$ & $10.84^{\mathrm{abc}}$ \\
$\mathrm{T}_{5}$ & $39.25^{\mathrm{a}}$ & 5.00 & $34.35^{\mathrm{a}}$ & $2.79^{\mathrm{a}}$ & $30.40^{\mathrm{a}}$ & $12.16^{\mathrm{a}}$ \\
$\mathrm{T}_{6}$ & $37.82^{\mathrm{ab}}$ & 5.00 & $32.16^{\mathrm{ab}}$ & $2.74^{\mathrm{ab}}$ & $29.10^{\mathrm{ab}}$ & $11.64^{\mathrm{a}}$ \\
$\mathrm{T}_{7}$ & $35.15^{\mathrm{bcd}}$ & 5.33 & $29.05^{\mathrm{b}-\mathrm{e}}$ & $2.63^{\mathrm{bcd}}$ & $26.80^{\mathrm{b}-\mathrm{e}}$ & $10.72^{\mathrm{a}-\mathrm{d}}$ \\
$\mathrm{T}_{8}$ & $34.18^{\mathrm{cd}}$ & 5.33 & $27.83^{\mathrm{b}-\mathrm{f}}$ & $2.59^{\mathrm{cde}}$ & $25.25^{\mathrm{c}-\mathrm{f}}$ & $10.10^{\mathrm{b}-\mathrm{e}}$ \\
$\mathrm{T}_{9}$ & $30.88^{\mathrm{ef}}$ & 5.33 & $25.91^{\mathrm{d}-\mathrm{h}}$ & $2.50^{\mathrm{efg}}$ & $23.45^{\mathrm{efg}}$ & $9.38^{\mathrm{def}}$ \\
$\mathrm{T}_{10}$ & $29.10^{\mathrm{fg}}$ & 5.00 & $25.15^{\mathrm{e}-\mathrm{h}}$ & $2.48^{\mathrm{efg}}$ & $21.90^{\mathrm{fgh}}$ & $8.76^{\mathrm{efg}}$ \\
$\mathrm{T}_{11}$ & $28.35^{\mathrm{fg}}$ & 5.67 & $23.33^{\mathrm{fgh}}$ & $2.46^{\mathrm{fg}}$ & $20.38^{\mathrm{gh}}$ & $8.15^{\mathrm{fg}}$ \\
$\mathrm{T}_{12}$ & $26.70^{\mathrm{gh}}$ & 5.67 & $22.67^{\mathrm{gh}}$ & $2.43^{\mathrm{fg}}$ & $18.55^{\mathrm{h}}$ & $7.42^{\mathrm{g}}$ \\
\hline Level of & 0.01 & $\mathrm{NS}$ & 0.01 & 0.01 & 0.01 & 0.01 \\
significance & & & & & & \\
\hline
\end{tabular}

Figures in a column having same letter(s) do not differ significantly at $1 \%$ level of significance as per DMRT.

Number of leaves/plant: Number of leaves/plant of summer onion was found insignificant when the influence of integrated $\mathrm{N}$ from urea, cowdung and vermicompost were compared (Table 2). The highest number of leaves/plant (6.00) was observed in treatment $T_{2}(120 \mathrm{~kg} \mathrm{~N} / \mathrm{ha}$ supplied from urea) followed by that $T_{3}, T_{11}$, and $T_{12}$ with the value of 5.67. Alternatively, the minimum number of leaves (4.98) per plant was found in $T_{1}$ treated plots, where no fertilizer was applied. This result is in agreement with the findings of El-Oksh et al. (1993). They observed that $\mathrm{N}$ application had no significant effect on number of leaves of onion. Singh et al. (1989) stated that a combination of $120 \mathrm{~kg} \mathrm{~N} / \mathrm{ha}$ with green manure gave the tallest plants and the maximum number of leaves/plant. Reddy and Reddy (2005) also observed that highest number of leaves per plant in onion was recorded with $30 \mathrm{t} / \mathrm{ha}$ vermicompost with $200 \mathrm{~kg}$ $\mathrm{N} / \mathrm{ha}$. Application of $80 \mathrm{~kg} \mathrm{~N} / \mathrm{ha}$ increased the number of leaves/plant compared to $40 \mathrm{~kg} \mathrm{~N} / \mathrm{ha}$ (Nehra et al., 1988). Kumar et al. (2001) found that $130 \mathrm{~kg} \mathrm{~N} / \mathrm{ha}$ resulted in the highest number of green leaves per plant of onion.

Leaf length: The study revealed that the longest leaf $(34.35 \mathrm{~cm})$ was observed when the field was incorporated with $80 \mathrm{~kg} \mathrm{~N} /$ hafrom urea and $40 \mathrm{~kg} \mathrm{~N} / \mathrm{ha}$ from 
cowdung $\left(T_{5}\right)$ followed by the treatment $T_{6}(80 \mathrm{~kg} \mathrm{~N} / \mathrm{ha}$ supplied from urea and $40 \mathrm{~kg}$ from vermicompost) with the value of $32.16 \mathrm{~cm}$ (Table 2). The shortest leaf $(21.20 \mathrm{~cm})$ was recorded in the treatment $\mathrm{T}_{1}$ receiving no organic or inorganic $\mathrm{N}$ fertilizer. Length of leaves decreased due to the sole application of urea, cowdung, and vermicompost compared to their integrated use. Singh et al. (1997) found that combination of different sources of organic manures viz., cowdung, farmyard manure, vermicompost, and inorganic fertilizer increased the leaf length of onion compared with their sole application. Singh et al. (2004) found that application of the highest $\mathrm{N}$ rate $(150 \mathrm{~kg} / \mathrm{ha})$ gave the highest leaf length $(28.22 \mathrm{~cm})$ of onion. Meena et al. (2007) stated the highest $\mathrm{N}$ level $(150$ $\mathrm{kg} / \mathrm{ha}$ ) gave the maximum length of the leaves in comparison to its lower levels i.e., 50 and $100 \mathrm{~kg} \mathrm{~N} / \mathrm{ha}$.

Bulb length: Integrated application of $\mathrm{N}$ from organic and inorganic sources showed significant variations in respect of bulb length of summer onion (Table 2 ). Bulb length increased due to the integration of inorganic and organic fertilizer. The highest bulb length $(2.79 \mathrm{~cm})$ was achieved from treatment $\mathrm{T}_{5}$ where $80 \mathrm{~kg} \mathrm{~N} / \mathrm{ha}$ supplied from urea and $40 \mathrm{~kg} \mathrm{~N} / \mathrm{ha}$ substituted by cowdung which was statistically identical with the treatment $\mathrm{T}_{6}(80 \mathrm{~kg} \mathrm{~N} / \mathrm{ha}$ supplied from urea with $40 \mathrm{~kg} \mathrm{~N} / \mathrm{ha}$ substituted by vermicompost) with a value of $2.74 \mathrm{~cm}$. On the contrary, control plot $\left(\mathrm{T}_{1}\right)$ gave the lowest bulb length $(2.40 \mathrm{~cm})$ of summer onion. The treatment receiving $120 \mathrm{~kg} \mathrm{~N} / \mathrm{ha}$ only from urea $\left(\mathrm{T}_{2}\right)$ was better than the treatment receiving $120 \mathrm{~kg} \mathrm{~N} / \mathrm{ha}$ only from cowdung $\left(\mathrm{T}_{11}\right)$ or $120 \mathrm{~kg} \mathrm{~N} / \mathrm{ha}$ only from vermicompost $\left(\mathrm{T}_{12}\right)$. Treatments $\mathrm{T}_{11}$ and $\mathrm{T}_{12}$ showed statistically similar result. Probably integration of organic and inorganic sources of $\mathrm{N}$ supplied the necessary requirements for the proper vegetative growth of plant that helps in obtaining the highest bulb length. Hussain et al. (1988) reported that organic manures increased the efficiency of chemical fertilizers. Similar views were reported by Reddy and Reddy (2005). They observed that combination of $30 \mathrm{t} / \mathrm{ha}$ vermicompost and $150 \mathrm{~kg} \mathrm{~N} / \mathrm{ha}$ gave the highest bulb length of onion. Pande and Mundra (1971) also stated that the bulb length of summer onion significantly increased by the application of $\mathrm{N}$. Bulb length of onion increased with increasing rates of $\mathrm{N}$ up to $125 \mathrm{~kg} / \mathrm{ha}$ (Haque et al., 2004).

Bulb weight: Significant variation in respect of bulb weight ( $g$ ) was observed when $\mathrm{N}$ was applied in an integrated manner (Table 2). There was a remarkable variation in bulb weight of summer onion among the twelve different treatments. The variation of bulb weight was recorded due to the application of $\mathrm{N}$ from different sources of organic and inorganic fertilizers. Results revealed that treatment $T_{5}$ where $80 \mathrm{~kg} \mathrm{~N} / \mathrm{ha}$ supplied from urea and $40 \mathrm{~kg} \mathrm{~N} / \mathrm{ha}$ substituted by cowdung gave the highest $(30.40 \mathrm{~g})$ bulb weight followed closely $(29.10 \mathrm{~g})$ by treatment $\mathrm{T}_{6}(80 \mathrm{~kg} \mathrm{~N} / \mathrm{ha}$ supplied from urea and $40 \mathrm{~kg} \mathrm{~N} / \mathrm{ha}$ substituted by vermicompost) which was statistically identical with treatment $T_{6}$. Treatment $T_{3}$ 
and $\mathrm{T}_{4}$ also showed statistically similar performance with the treatment $\mathrm{T}_{5}$. In contrast, the lowest bulb weight $(14.90 \mathrm{~g})$ was obtained from $\mathrm{T}_{1}$ (control) treatment. Like bulb diameter and bulb length, bulb weight was increased by the integrated use of $\mathrm{N}$ compared to sole use of $\mathrm{N}$ from urea. However, treatment $\mathrm{T}_{9}$ (40 kg N/ha supplied from urea and $80 \mathrm{~kg} \mathrm{~N} / \mathrm{ha}$ substituted by cowdung) and $\mathrm{T}_{10}$ (40 kg/ha N supplied from urea and $80 \mathrm{~kg} \mathrm{~N} / \mathrm{ha}$ substituted by vermicompost) gave inferior results compared to treatment $\mathrm{T}_{2}$ where $120 \mathrm{~kg} / \mathrm{ha} \mathrm{N}$ supplied only from urea. Singh et al. (2004) also observed similar results in kharif onion (Allium cepa) $\mathrm{cv}$. N53. They found that the average bulb weight increased significantly up to $120 \mathrm{~kg} \mathrm{~N} / \mathrm{ha}$ and FYM at $10 \mathrm{t} / \mathrm{ha}$. Haque et al. (2004) stated that application of $125 \mathrm{~kg} \mathrm{~N} / \mathrm{ha}$ increased bulb weight. Singh et al. (1997) recorded the highest fresh weight of bulb $(47.48 \mathrm{~g})$ with $150 \mathrm{~kg} \mathrm{~N} / \mathrm{ha}$.

Bulb yield: The results of bulb yield are presented in Table 2. The highest bulb yield of $12.16 \mathrm{t} / \mathrm{ha}$ was recorded in treatment $\mathrm{T}_{5}$ receiving $80 \mathrm{~kg} \mathrm{~N} / \mathrm{ha}$ from urea and $40 \mathrm{~kg} \mathrm{~N}$ substituted by cowdung followed by the treatments $\mathrm{T}_{6}, \mathrm{~T}_{3}, \mathrm{~T}_{4}$, and $\mathrm{T}_{7}$ which were statistically identical. Treatments receiving $120 \mathrm{~kg} \mathrm{~N}$ from urea $\left(\mathrm{T}_{2}\right), 40 \mathrm{~kg} \mathrm{~N} / \mathrm{ha}$ from urea and rest of the $80 \mathrm{~kg} \mathrm{~N} / \mathrm{ha}$ substituted by either cowdung or vermicompost $\left(\mathrm{T}_{9}\right.$ and $\left.\mathrm{T}_{10}\right)$ produced comparable yields but were significantly lower than the treatments $\mathrm{T}_{5}$ and $\mathrm{T}_{6}$. Treatments receiving $\mathrm{N}$ solely from cowdung and vermicompost $\left(\mathrm{T}_{11}\right.$ and $\left.\mathrm{T}_{12}\right)$ produced lower bulb yield compared with the other fertilizer treatments. The lowest bulb yield $(5.96 \mathrm{t} / \mathrm{ha})$ was obtained from $\mathrm{T}_{1}$ treatment. Cowdung showed better performance compared to vermicompost may be due to the slower mineralization of vermicompost. Similar results were achieved by Abbey and Kanton (2004). They stated that onion bulb yield due to the FYM with inorganic fertilizer treatment was $34.1 \%$ higher than that for FYM, and $4.6 \%$ higher than that for the inorganic fertilizer treatment. Application of FYM either alone or in combination with inorganic fertilizer significantly $(\mathrm{P}<0.05)$ reduced bulb rot and use of both FYM with inorganic fertilizer at half their recommended rates increased onion bulb yield and reduced field defects. Singh et al. (1997) found that the combination of green manure, farmyard manure ( $25 \mathrm{t} / \mathrm{ha})$, vermicompost $(2 \mathrm{t} / \mathrm{ha})$ and $100 \mathrm{~kg} \mathrm{~N} / \mathrm{ha}$, yields were increased to $323.1 \mathrm{t} / \mathrm{ha}$. Reddy and Reddy (2005) noticed that yield of onion increased significantly with increasing levels of vermicompost and nitrogen fertilizer and the highest yield was recorded with vermicompost at 30 t/ha with $150 \mathrm{~kg} \mathrm{~N} / \mathrm{ha}$.

\section{Nutrient concentrations in the onion bulb}

Nitrogen content: Table 3 presents the $\mathrm{N}$ concentration in bulb of summer onion at harvest. The highest $\mathrm{N}$ concentration $(2.30 \%)$ was recorded in the treatment $\mathrm{T}_{5}$ ( $80 \mathrm{~kg} \mathrm{~N} / \mathrm{ha}$ supplied from urea with $40 \mathrm{~kg} \mathrm{~N} / \mathrm{ha}$ substituted by cowdung) which was statistically identical with treatment $T_{6}(80 \mathrm{~kg} \mathrm{~N} / \mathrm{ha}$ supplied from urea with 
$40 \mathrm{~kg} \mathrm{~N} / \mathrm{ha}$ substituted by vermicompost). Conversely, lowest $\mathrm{N}$ concentration $(1.41 \%)$ was found in treatment $\mathrm{T}_{1}$ (control). These observations are in accordance with those of Metwally and Khamis (1998) who reported that combination of organic and inorganic $\mathrm{N}$ resulted in greater values of apparent net $\mathrm{N}$ release than those obtained when each was applied singly. They also observed that the best mixture ratio between organic and inorganic $\mathrm{N}$ sources was 1: 1, which partially agrees with the present findings. Hedge (1988) stated that $\mathrm{N}$ fertilization increased the $\mathrm{N}, \mathrm{Ca}$, and $\mathrm{Mg}$ concentrations in the bulb of onion. Maximum $\mathrm{N}$ content by the bulb of summer onion was observed when organic $\mathrm{N}$ was applied with inorganic $\mathrm{N}$ up to a certain limit.

Table 3. Effect of integrated use of nitrogen on the nutrient concentrations of summer onion bulb.

\begin{tabular}{c|cc|c|c}
\hline \multirow{2}{*}{ Treatments } & \multicolumn{4}{|c}{ Nutrients $(\%)$} \\
\cline { 2 - 5 } & Nitrogen & Phosphorus & Potassium & Sulphur \\
\hline $\mathrm{T}_{1}$ & $1.41^{\mathrm{j}}$ & $0.055^{\mathrm{h}}$ & $0.89^{\mathrm{h}}$ & $0.66^{\mathrm{f}}$ \\
$\mathrm{T}_{2}$ & $1.85^{\mathrm{ef}}$ & $0.103^{\mathrm{def}}$ & $1.36^{\mathrm{c}-\mathrm{f}}$ & $0.77^{\mathrm{c}-\mathrm{f}}$ \\
$\mathrm{T}_{3}$ & $2.19^{\mathrm{ab}}$ & $0.166^{\mathrm{ab}}$ & $1.56^{\mathrm{abc}}$ & $0.88^{\mathrm{abc}}$ \\
$\mathrm{T}_{4}$ & $2.10^{\mathrm{bc}}$ & $0.147^{\mathrm{bc}}$ & $1.50^{\mathrm{a}-\mathrm{d}}$ & $0.85^{\mathrm{a}-\mathrm{d}}$ \\
$\mathrm{T}_{5}$ & $2.30^{\mathrm{a}}$ & $0.185^{\mathrm{a}}$ & $1.71^{\mathrm{a}}$ & $0.96^{\mathrm{a}}$ \\
$\mathrm{T}_{6}$ & $2.24^{\mathrm{a}}$ & $0.173^{\mathrm{ab}}$ & $1.62^{\mathrm{ab}}$ & $0.91^{\mathrm{ab}}$ \\
$\mathrm{T}_{7}$ & $2.01^{\mathrm{cd}}$ & $0.126^{\mathrm{cd}}$ & $1.48^{\mathrm{a}-\mathrm{d}}$ & $0.81^{\mathrm{b}-\mathrm{e}}$ \\
$\mathrm{T}_{8}$ & $1.93^{\mathrm{de}}$ & $0.112^{\mathrm{de}}$ & $1.42^{\mathrm{b}-\mathrm{e}}$ & $0.79^{\mathrm{b}-\mathrm{f}}$ \\
$\mathrm{T}_{9}$ & $1.78^{\mathrm{fg}}$ & $0.093^{\mathrm{efg}}$ & $1.28^{\mathrm{d}-\mathrm{g}}$ & $0.75^{\mathrm{c}-\mathrm{f}}$ \\
$\mathrm{T}_{10}$ & $1.69^{\mathrm{gh}}$ & $0.085^{\mathrm{efg}}$ & $1.21^{\mathrm{efg}}$ & $0.73^{\mathrm{def}}$ \\
$\mathrm{T}_{11}$ & $1.61^{\mathrm{hi}}$ & $0.078^{\mathrm{fg}}$ & $1.15^{\mathrm{fg}}$ & $0.71^{\text {def }}$ \\
$\mathrm{T}_{12}$ & $1.55^{\mathrm{i}}$ & $0.069^{\mathrm{gh}}$ & $1.10^{\mathrm{gh}}$ & $0.70^{\mathrm{ef}}$ \\
\hline Level of significance & 0.01 & 0.01 & 0.01 & 0.01 \\
\hline
\end{tabular}

Figures in a column having same letter(s) do not differ significantly at $1 \%$ level of significance as per DMRT.

Phosphorus content: The phosphorus content in onion bulb as improved by different combinations of $\mathrm{N}$ from urea, cowdung, and vermicompost showed a statistically significant variation (Table 3 ). With the twelve different treatments, the highest phosphorous concentration in bulb $(0.185 \%)$ was recorded from treatment $\mathrm{T}_{5}(80 \mathrm{~kg} \mathrm{~N} / \mathrm{ha}$ supplied from urea with $40 \mathrm{~kg} \mathrm{~N} / \mathrm{ha}$ substituted by cowdung). Statistically identical performance was observed in treatment $\mathrm{T}_{6}(80$ $\mathrm{kg} \mathrm{N} / \mathrm{ha}$ supplied from urea with $40 \mathrm{~kg} \mathrm{~N} / \mathrm{ha}$ substituted by vermicompost) and 
treatment $\mathrm{T}_{3}(100 \mathrm{~kg} \mathrm{~N} / \mathrm{ha}$ supplied from urea with $20 \mathrm{~kg} \mathrm{~N} / \mathrm{ha}$ substituted by vermicompost), whereas the lowest phosphorous concentration $(0.055 \%)$ was found in control $\left(\mathrm{T}_{1}\right)$. Kumar et al. (2006) found that the phosphorus content of bulb was increased significantly over the control with the application of $150 \mathrm{~kg}$ $\mathrm{N} / \mathrm{ha}$. Coolong et al. (2004) stated that in onion bulbs $\mathrm{N}$ and $\mathrm{P}$ content was increased by $\mathrm{N}$ application. These results were in agreement with earlier reports on nutrient concentration and uptake was increased due to fertilization of crop (Nakashgir et al., 2000).

Potassium content: It was observed from the study that the highest potassium content $(1.71 \%)$ was recorded in treatment $\mathrm{T}_{5}(80 \mathrm{~kg} \mathrm{~N} / \mathrm{ha}$ supplied from urea with $40 \mathrm{~kg} \mathrm{~N} /$ ha substituted by cowdung), which was closely followed (1.62\%) by treatment $T_{6}$ (Table 3 ). The potassium concentration of treatment $T_{3}$ and $T_{4}$ were also statistically similar with the treatment $\mathrm{T}_{5}$. Control plots $\left(\mathrm{T}_{1}\right)$ showed significantly the lowest potassium concentration $(0.89 \%)$. It was observed that the combined application of $\mathrm{N}$ increased potassium content in onion bulb compared to other treatments. Yoldas et al. (2011) reported that the rise of $\mathrm{K}$ content in bulb depends on increasing cattle manure doses and it was maximum $(4.09 \%)$ at $60 \mathrm{t} / \mathrm{ha}$ dose. But 20 and $40 \mathrm{t} / \mathrm{ha}$ doses of organic manure and mineral $\mathrm{N}, \mathrm{P}, \mathrm{K}$ application were in the same statistical group.

Sulphur content: A statistically remarkable variation was observed regarding the sulphur concentration in bulbs of summer onion (Table 3). The highest sulphur concentration $(0.96 \%)$ was observed in the treatment $T_{5}(80 \mathrm{~kg} \mathrm{~N} / \mathrm{ha}$ supplied from urea with $40 \mathrm{~kg} \mathrm{~N} /$ ha substituted by cowdung) which was statistically similar with treatment $\mathrm{T}_{6}(80 \mathrm{~kg} \mathrm{~N} / \mathrm{ha}$ supplied from urea with $40 \mathrm{~kg} \mathrm{~N} / \mathrm{ha}$ substituted by vermicompost) with a value of $0.91 \%$. A positive response of onion towards $\mathrm{N}$ and sulphur in terms of yield and quality of bulbs was reported by Vachhani and Patel (1993). Moreover, sulphur is considered essential for building up of sulphur containing amino acids and also for a good vegetative growth and bulb development in onion (Anwar et al., 2001). In contrast, the lowest sulphur concentration $(0.66 \%)$ was found in treatment $\mathrm{T}_{1}$ (control). This might be due to the fact that the combined effect of $\mathrm{N}$ from organic and inorganic sources played positive effect on sulphur accumulation in the bulb of summer onion up to a certain limit. These results are also in conformity with the findings of Singh et al. (1995) who found the combined effect of $\mathrm{N}$ and sulphur on $\mathrm{N}$ uptake to be synergistic.

\section{Nutrient concentrations in the onion leaves}

Nitrogen content: The effect of integrated use of $\mathrm{N}$ revealed that the treatment $\mathrm{T}_{5}$ ( $80 \mathrm{~kg} \mathrm{~N} / \mathrm{ha}$ supplied from urea with $40 \mathrm{~kg} \mathrm{~N} / \mathrm{ha}$ substituted by cowdung) showed the highest $\mathrm{N}$ concentration $(2.91 \%)$ in the leaf of summer onion (Table 4). Statistically identical performance was observed in the treatment $T_{6}$ where $80 \mathrm{~kg}$ 
$\mathrm{N} /$ ha supplied from urea with $40 \mathrm{~kg} \mathrm{~N} /$ ha substituted by vermicompost. The next highest $\mathrm{N}$ content was obtained in treatment $\mathrm{T}_{3}$ and $\mathrm{T}_{4}$. On the contrary, significantly lowest $\mathrm{N}$ concentration $(2.15 \%)$ was recorded in the treatment $\mathrm{T}_{1}$ where none of the fertilizers was applied. Probably, maximum $\mathrm{N}$ concentration in the leaf of summer onion was observed when organic $\mathrm{N}$ was applied with inorganic $\mathrm{N}$ up to a certain limit, after that sole application performed better. Similar results were found by Metwally and Khamis (1998). They reported that combination of organic and inorganic $\mathrm{N}$ resulted in greater values of apparent net $\mathrm{N}$ release than those obtained when each was applied singly.

Table 4. Effect of integrated use of nitrogen on the nutrient concentrations in the leaf of summer onion.

\begin{tabular}{c|c|c|c|c}
\hline \multirow{2}{*}{ Treatments } & \multicolumn{4}{|c}{ Nutrients (\%) } \\
\cline { 2 - 5 } & Nitrogen & Phosphorus & Potassium & Sulphur \\
\hline $\mathrm{T}_{1}$ & $2.15^{\mathrm{i}}$ & $0.053^{\mathrm{k}}$ & $1.71^{\mathrm{b}}$ & $0.63^{\mathrm{f}}$ \\
$\mathrm{T}_{2}$ & $2.51^{\mathrm{efg}}$ & $0.086^{\mathrm{fg}}$ & $2.22^{\mathrm{a}}$ & $0.76^{\mathrm{c}-\mathrm{f}}$ \\
$\mathrm{T}_{3}$ & $2.75^{\mathrm{bc}}$ & $0.153^{\mathrm{c}}$ & $2.38^{\mathrm{a}}$ & $0.89^{\mathrm{abc}}$ \\
$\mathrm{T}_{4}$ & $2.69^{\mathrm{cd}}$ & $0.133^{\mathrm{d}}$ & $2.34^{\mathrm{a}}$ & $0.87^{\mathrm{a}-\mathrm{d}}$ \\
$\mathrm{T}_{5}$ & $2.91^{\mathrm{a}}$ & $0.183^{\mathrm{a}}$ & $2.45^{\mathrm{a}}$ & $0.98^{\mathrm{a}}$ \\
$\mathrm{T}_{6}$ & $2.83^{\mathrm{ab}}$ & $0.166^{\mathrm{b}}$ & $2.41^{\mathrm{a}}$ & $0.94^{\mathrm{ab}}$ \\
$\mathrm{T}_{7}$ & $2.61^{\mathrm{de}}$ & $0.107^{\mathrm{e}}$ & $2.31^{\mathrm{a}}$ & $0.84^{\mathrm{a}-\mathrm{e}}$ \\
$\mathrm{T}_{8}$ & $2.55^{\mathrm{ef}}$ & $0.093^{\mathrm{f}}$ & $2.27^{\mathrm{a}}$ & $0.79^{\mathrm{b}-\mathrm{f}}$ \\
$\mathrm{T}_{9}$ & $2.46^{\mathrm{fgh}}$ & $0.080^{\mathrm{gh}}$ & $2.19^{\mathrm{a}}$ & $0.74^{\mathrm{c}-\mathrm{f}}$ \\
$\mathrm{T}_{10}$ & $2.41^{\mathrm{gh}}$ & $0.073^{\mathrm{hi}}$ & $2.15^{\mathrm{a}}$ & $0.71^{\mathrm{def}}$ \\
$\mathrm{T}_{11}$ & $2.40^{\mathrm{gh}}$ & $0.067^{\mathrm{jj}}$ & $2.11^{\mathrm{a}}$ & $0.69^{\mathrm{ef}}$ \\
$\mathrm{T}_{12}$ & $2.39^{\mathrm{h}}$ & $0.060^{\mathrm{jk}}$ & $2.05^{\mathrm{ab}}$ & $0.68^{\mathrm{ef}}$ \\
\hline Level of significance & 0.01 & 0.01 & 0.01 & 0.01 \\
\hline
\end{tabular}

Figures in a column having same letter(s) do not differ significantly at $1 \%$ level of significance as per DMRT.

Hedge (1988) noticed that the $\mathrm{N}, \mathrm{Ca}$, and $\mathrm{Mg}$ concentrations in the leaf of onion was increased by the $\mathrm{N}$ fertilization. Kumar et al. (2006) also found that the application of $150 \mathrm{~kg} \mathrm{~N} / \mathrm{ha}$ significantly increased the $\mathrm{N}$ content in the leaves of onion over the control. Boyhan et al. (2007) reported that leaf tissue $\mathrm{N}$ had a significant quadratic effect that ranged from $18.2 \mathrm{mg} / \mathrm{g}$ to $36.3 \mathrm{mg} / \mathrm{g}$ with $\mathrm{N}$ fertilizer rates of 0 to $336 \mathrm{~kg} / \mathrm{ha}$. They also found that leaf tissue $\mathrm{N}$ levels generally did not differ much over the range of $\mathrm{N}$ fertilizer except for the $0 \mathrm{~kg} / \mathrm{ha}$ $\mathrm{N}$ treatment where $\mathrm{N}$ fertilizer with a rate of $84 \mathrm{~kg} / \mathrm{ha}$ resulted in lowest leaf tissue $\mathrm{N}$ content which was $37 \%$ greater than the control or $0 \mathrm{~kg} / \mathrm{ha}$ rate. 
Phosphorus content: The phosphorus content of leaves of summer onion at harvest showed a statistically significant variation (Table 4). The highest phosphorous concentration in leaves $(0.183 \%)$ was recorded in the treatment $\mathrm{T}_{5}$ where $80 \mathrm{~kg} \mathrm{~N} / \mathrm{ha}$ supplied from urea with $40 \mathrm{~kg} \mathrm{~N} / \mathrm{ha}$ substituted by cowdung. Alternatively, the lowest phosphorous concentration $(0.053 \%)$ was found in treatment $\mathrm{T}_{1}$ receiving no organic or inorganic fertilizers. The highest content of the nutrient in the plant might be due to application of most favourable rate of organic or inorganic fertilizers in treatment $\mathrm{T}_{5}$ which are in agreement with the previous findings of Jha et al. (2000). According to Kumar et al. (2006), significant rise in phosphorous concentration was recorded in the leaves of onion grown under $150 \mathrm{~kg} \mathrm{~N} / \mathrm{ha}$ application.

Potassium content: The leaf of summer onion showed significant variations in respect of potassium concentration after harvest when $\mathrm{N}$ was applied from different organic and inorganic sources (urea, cowdung, and vermicompost) are presented in Table 4. Among the different treatments, application of $80 \mathrm{~kg} \mathrm{~N} / \mathrm{ha}$ from urea with $40 \mathrm{~kg} \mathrm{~N} / \mathrm{ha}$ substituted by cowdung $\left(\mathrm{T}_{5}\right)$ showed the highest $(2.45 \%)$ potassium concentration which was closely followed $(2.41 \%)$ by treatment $\mathrm{T}_{6}(80 \mathrm{~kg} \mathrm{~N} / \mathrm{ha}$ supplied from urea with $40 \mathrm{~kg} \mathrm{~N} / \mathrm{ha}$ substituted by vermicompost). The next highest potassium concentration was achieved in $T_{3}$ and $\mathrm{T}_{4}$ treatment. Control plot $\left(\mathrm{T}_{1}\right)$ showed significantly lowest potassium concentration $(1.71 \%)$. It was observed that all the treatment combinations showed statistically similar values of potassium concentration except $\mathrm{T}_{1}$ and $\mathrm{T}_{12}$. Significant linear increase in potassium content of onion leaves with increasing $\mathrm{N}$ fertilizer was recorded that peaked with $140 \mathrm{~kg} / \mathrm{ha} \mathrm{N}$ fertilizer (Boyhan et al., 2007).

Sulphur content: Sulphur concentration in the leaves of summer onion after harvest also showed variable response to different doses of $\mathrm{N}$ fertilizer treatments (Table 4). The performances of the most of the treatments differ significantly from each other. The highest sulphur concentration in the leaves $(0.98 \%)$ was observed in the treatment $T_{5}(80 \mathrm{~kg} \mathrm{~N} / \mathrm{ha}$ supplied from urea with $40 \mathrm{~kg} \mathrm{~N} / \mathrm{ha}$ substituted by cowdung) which was statistically similar with treatment $\mathrm{T}_{6}(80 \mathrm{~kg}$ $\mathrm{N} / \mathrm{ha}$ supplied from urea with $40 \mathrm{~kg} \mathrm{~N} / \mathrm{ha}$ substituted by vermicompost) with a value of $0.94 \%$. Treatment $\mathrm{T}_{3}, \mathrm{~T}_{4}, \mathrm{~T}_{6}$ also showed statistically identical performance. Conversely, the lowest sulphur concentration $(0.63 \%)$ was found in treatment $\mathrm{T}_{1}$ where no fertilizer was applied. This might be due to the integrated effect of $\mathrm{N}$ from organic and inorganic sources played positive effect on sulphur concentration in the leaves of summer onion up to a certain limit (Rodr1'guez et al., 1999; Sharma et al., 2003). These findings were also in agreement with Boyhan et al. (2007) who recorded 0.37 to $0.7 \%$ sulphur content in onion leaves grown under different $\mathrm{N}$ fertilizer rates. 


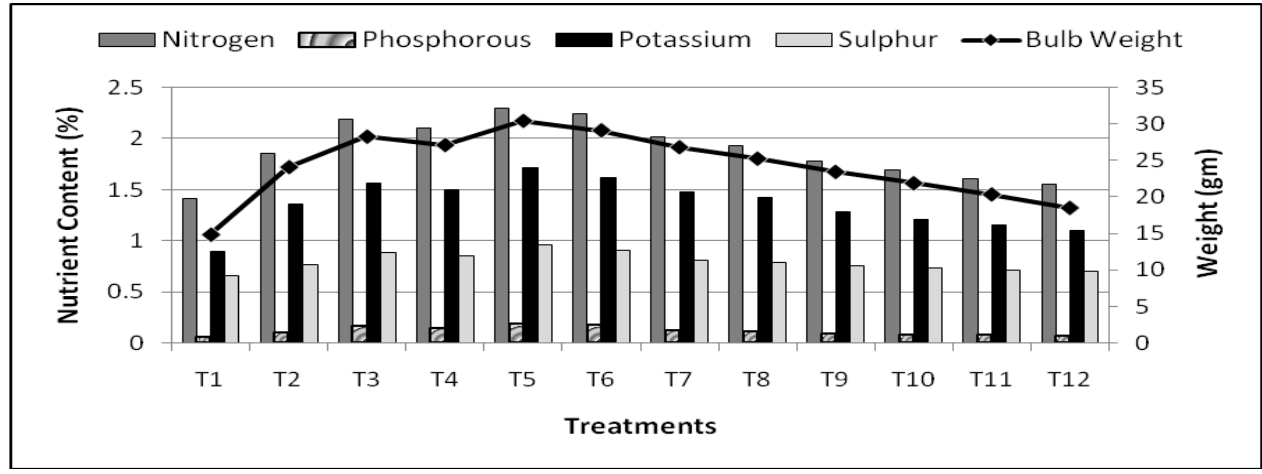

Fig. 1. Relationship between the weight and nutrient contents of summer onion (Allium cepa var. BARI Piaz-2) bulb.

Almost a linear relationship between onion bulb weight and macro nutrient content was observed in the present experiment (Fig. 1). Highest N, P, K, and S contents of onion bulb were recorded in $\mathrm{T}_{5}$ which was clearly reflected by the highest bulb weight. A similar trend was observed in terms of nutrient contents and bulb weight in case of $\mathrm{T}_{6}$. From the ongoing discussion it may be inferred that the weight as well as yield of onion bulbs showed highest increase where 40 $\mathrm{kg} / \mathrm{ha} \mathrm{N}$ was supplied from organic source viz., cowdung and vermicompost.

Higher and lower rate of organic $\mathrm{N}$ application resulted in the onion crop to respond negatively in terms of above mentioned parameters. Synergistic effect on weight and protein content in the onion bulb by integrated application of $\mathrm{N}$ and $\mathrm{P}$ was reported by Kumar et al. (2006). In case of onion leaves, $\mathrm{T}_{5}$ where one third of recommended $120 \mathrm{~kg} \mathrm{~N} / \mathrm{ha}$ supplied from cowdung showed highest leaf length as well major macronutrient contents (Fig. 2). This was followed by $\mathrm{T}_{6}$ with one third of total $\mathrm{N}$ supplied from vermicompost. These results were in conformity with Fujime et al. (2001) who reported similar findings for sewage sludge treated onion crops.

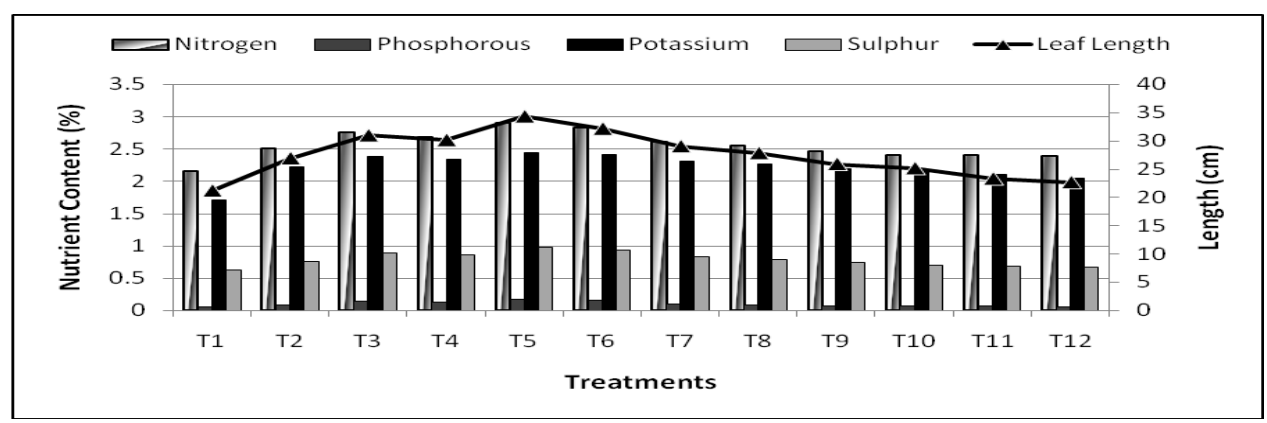

Fig. 2. Relationship between the length and nutrient contents of summer onion (Allium cepa var. BARI Piaz-2) leaves. 


\section{Conclusion}

Integrated use of organic and inorganic $\mathrm{N}$ resulted in higher nutrient content in onion bulb and leaf, which ultimately reflected in maximizing growth parameters and bulb yield of onion. A package of $80 \mathrm{~kg} \mathrm{~N}$ from urea and $40 \mathrm{~kg} \mathrm{~N}$ from cowdung (at the rate of $8 \mathrm{t} / \mathrm{ha}$ ) along with a blanket dose of $44 \mathrm{~kg} \mathrm{P}, 100 \mathrm{~kg} \mathrm{~K}$, and $32 \mathrm{~kg} \mathrm{~S} / \mathrm{ha}$ appeared as the best suited combination and thus may be recommended for the cultivation of summer onion in the study and alike areas of the country.

\section{References}

Abbey, L. and R. A. L. Kanton. 2004. Fertilizer type, but not time of cessation of irrigation affect onion development and yield in a semi-arid region. J. Veg. Crop Prod. 9(2): 41-48.

Anwar, M. N., J. U. Sarker, M. Rahman, M. A. Islam and M. Begum. 2001. Response of onion to N, phosphorus, potassium, sulphur and zinc. Bangladesh J. Environ. Sci. 7: 68-72.

BBS. 2004. Year Book of Agricultural Statistics of Bangladesh. Bangladesh Bureau of Statistics, Statistics Division, Ministry of planning, Government of the Peoples Republic of Bangladesh. Dhaka. P. 143.

BMD. 2007. Bangladesh Meteorological Department. Ministry of Defense, People's Republic of Bangladesh. Available at http//: www.bmd.gov.bd (Accessed on 23/07/2007).

Boyhan, G.E., R.L. Torrance and C.R. Hill. 2007. Effects of N, phosphorus, and potassium rates and fertilizer sources on yield and leaf nutrient status of short-day onions. Hortscience 42(3): 653-660.

Bremner, J. M. and C. S. Mulvaney. 1982. Total N. In: R.H. Miller and D.R. Keeny (eds.) Methods of Soil Analysis. American Society of Agronomy Inc. Madison, Wisconsin, USA, Pp. 595-622.

Brewster, J. L. and H. A. Butler. 1989. Effects of N supply on bulb development in onion (Allium cepa L.). J. Exp. Bot. 40: 1155-1162.

Coolong, W., T. Kopsell, D. A. Kopsell and D. A. W. M. Randle. 2004. N and sulfur influence nutrient usage and accumulation in onion (Allium cepa L.). J. Plant Nutr. 27(9): 1667-1686.

El-Oksh, I. I., A. M. El-Gizawy, M. M. F. Abdallah, A. R. A. G. Mohamed and A. A. G. Abdalla. 1993. Effect of soil moisture and $\mathrm{N}$ fertilizer levels on onion grown in mixture of talfa and sand. Bull. Fac. Agric. Univ. Cairo 44(1): 145-156

FAO. 2011. United Nation's Food and Agricultural Organization, Rome, Italy. Retrieved from http://faostat.fao.org/site/567/default.aspx (Accessed on 03/04/2013).

Fujime, Y., N. Okuda, T. Nishio and M. Guangyun. 2001. Utilization of excreta ashes in vegetable cultivation. Sci. Rep. Kyoto Pref. Uni. Human Envi. Agric. 53: 35-38.

Gomez, A. K. and A. A. Gomez. 1984. Statistical Procedures for Agricultural Research. $2^{\text {nd }}$ edn. John Wiley and Sons, New York, USA, 680 Pp. 
Haque, M. I., M. M. Zaman, M. K. Hasan, M. Begum and F. Pervin. 2004. Growth and yield of onion as influenced by $\mathrm{N}$ and irrigation. J. Agric. Ext. Rural Dev. 2(1): 151153.

Hedge, D. M. 1988. Effect of irrigation and N fertilization on yield, quality, nutrient uptake and water use of onion (Allium cepa L.). Singapore J. Pri. Ind. 16(2): 111-123.

Hossain, A. K. M. A. and J. Islam. 1994. Status of Allium production in Bangladesh. Acta Hortic. 358: 33-36.

Hunt, J. 1980. Determination of total sulphur in small amount of plant material. Analyst. 105: $83-85$.

Hussain, T., G. Jullani and M. Z. Iqbal. 1988. Integrated use of organic and inorganic N fertilizer in rice-wheat cropping system. Pakistan J. Soil Sci. 3:19-23.

Jayathilake, P. K. S., I.P. Reddy, D. Srihari, K. R. Reddy and G. Neeraja. 2003. Integrated nutrient management in onion (Allium cepa L.). Trop. Agri. Res. 15: 1-9.

Jha, A. K., N. Pal and N. Singh. 2000. Phosphorus uptake and its utilization by onion varieties at different stages of growth. Indian J. Hort. 57: 347-350.

Kumar, A., R. Singh and R. K. Chhillar. 2001. Influence of N and potassium application on growth, yield and nutrient uptake by onion (Allium cepa L.). Indian J. Agron. 46(4): $742-746$.

Kumar, D., S. Kumar and A. Kumar. 2001. Effect of different levels of N on growth and yield of onion (Allium cepa L.). Agr. Sci. Digest. 21(2): 121-123.

Kumar, S., C. P. Tiwari and V. Singh. 2006. Bulb yield and quality of onion (Allium cepa L.) as affected by application rates of $\mathrm{N}$ and potassium fertilizer. Agr. Sci. Digest. 26(1): $11-14$

Mallik, M. S. A. 2011. Seed Production of Summer Onion Varieties. KGF technical bulletin. No. 15, BARC, Farmgate, Dhaka-1215, P. 4.

Meena, P. M., V. K. Umrao, A. Kumar and R. Kumar. 2007. Effect of N doses on growth and yield of onion (Allium cepa L.) cv. 'Nasik Red'. Agr. Sci. Digest. 27(2): 144-145.

Metwally, S.M. and M.A. Khamis. 1998. Comparative effects of organic and inorganic N sources applied to a sandy soil on availability of $\mathrm{N}$ and wheat yield. Egypt. J. Soil Sci. 38(1-4): 35-54.

Murphy, J. and J. P. Riley. 1962. A modified single solution method for the determination of Phosphate in natural waters. Anal. Chim. Acta. 27: 31-36.

Nakashgir, G. H., G. M. Handoo and S. A. Wani. 2000. Transformation, availability and relative response of rice to applied $\mathrm{K}$ in presence of ammonical $\mathrm{N}$ in Alfisols of Kashmir. J. Potassium Res. 16: 55-58.

Nasreen, S. and A. K. M. Hossain. 2000. Influence of chemical fertilizers and organic manure on the growth and yield of onion. Bangladesh J. Agril. Res. 25(2): 221-231.

Nehra, B. K., M. L. Pandita and K. Singh, 1988. Effect of bulb size, spacing and N on plant growth and yield of onion. Harayena J. Hort. Sci. 17(1-2): 106-110.

Pande, R. C. and R. S. Mundra. 1971. Note on response of onion (Allium cepa L.) to varying levels of N, P and K. Indian J. Agril. Sci. 41(2): 107-108. 
Pandita, M. L. 1994. Status of Allium production and research in India. Acta Hort. 358: 79-86.

Rai, M. M. 1981. Principles of Soil Science. MacMillan India Ltd., Calcutta, Pp. 179182.

Randle, W. M. 2000. Increasing N concentration in hydroponics solution affects onion flavor and bulb quality. J. Am. Soc. Hort. Sci. 125: 254-259.

Rao, K. R., P. A. Rao and K. T. Rao. 2000. Influence of organic manure and fertilizers on the incidence of groundnut leafminer. Dev. Annals of Plant Prot. Sci. 9(1): 12-15.

Reddy, K. C. and K. M. Reddy, 2005. Differential levels of vermicompost and N on growth and yield in onion (Allium cepa L.)-radish (Raphanus sativus L.) cropping system. J. Res. ANGRAU, 33(1): 11-17.

Rodrı'guez, S. N., N. C. Belmar and P.A. Valenzuela. 1999. Effect of N, phosphorus and potassium rates, sources and forms upon onion (Allium cepa) bulb yield and quality. Agricultura Técnica (Santiago), 59: 122-132.

Rumpel, J. 1998. Effect of long-term organic, mineral, and combined organic-mineral fertilization on yield of onions (Allium cepa L.) grown from seeds. Biuletyn Warzywniczy 48: 5-15.

Shaheen, A., M. Fatma, A. Rizk and S. M. Singer. 2007. Growing onion plants without chemical fertilization. Res. J. Agr. Biol. Sci. 3(2): 95-104.

Sharma, R. P., N. Datt and P. K. Sharma. 2003. Combined application of N, phosphorus, potassium, and farmyard manure in onion (Allium cepa) under high hills, dry temperate conditions of north-western Himalayas. Indian J. Agr. Sci. 73: 225-227.

Singh, L., S.R. Bhonde and V.K. Mishra. 1997. Effect of different organic manures and inorganic fertilizers on yield and quality of rabi onion. NHRDF Newsletter 17(3): 1-3.

Singh, S., P. K. Yadav and B. Singh. 2004. Effect of N and potassium on growth and yield of onion (Allium cepa L.) cv. Pusa Red. Haryana J. Hort. Sci. 33(3-4): 308-309.

Singh, T., S. B. Singh and B. N. Singh. 1989. Effect of N, potassium and green manuring on growth and yield of rainy season onion (Allium cepa L.). Narindra Deva J. Agric. Res. 4(1): 57-60.

Singh. F., V. V. Singh and R.V. S. Mallik. 1995. Effect of different doses and sources of sulphur on yield and uptake of sulphur by garlic. J. Indian Soc. Soil Sci. 43: 130-131.

Snyman, H. G., D. E. Jong and T. A. S. Aveling 1998. The stabilization of sewage sludge applied to agricultural land and the effects on maize seedlings. Water Sci. Technol. 38(2): 87-95.

Vachhani, M. U. and Z. O. Patel. 1993. Effect of N, phosphours and potash on bulb yield and quality of onion (Allium cepa). Indian J. Agron. 3: 333-334.

Vasanthi, D. and K. Kumaraswamy. 1999. Effect of vermicompost to improve soil fertility and rice yield. J. Indian Soc. Soil Sci. 47(2): 268-272.

Yoldas, F., S. Ceylan, N. Mordogan and B. C. Esetlili. 2011. Effect of organic and inorganic fertilizers on yield and mineral content of onion (Allium cepa L.). Afr. J. Biotechnol. 10(55): 11488-11492. 